Historic, Archive Document

Do not assume content reflects current scientific knowledge, policies, or practices. 



\section{Technical Feasibility of Producing Particleboard from Black Hills Ponderosa Pine}

Donald C. Markstrom William F. Lehmann J. Dobbin McNatt

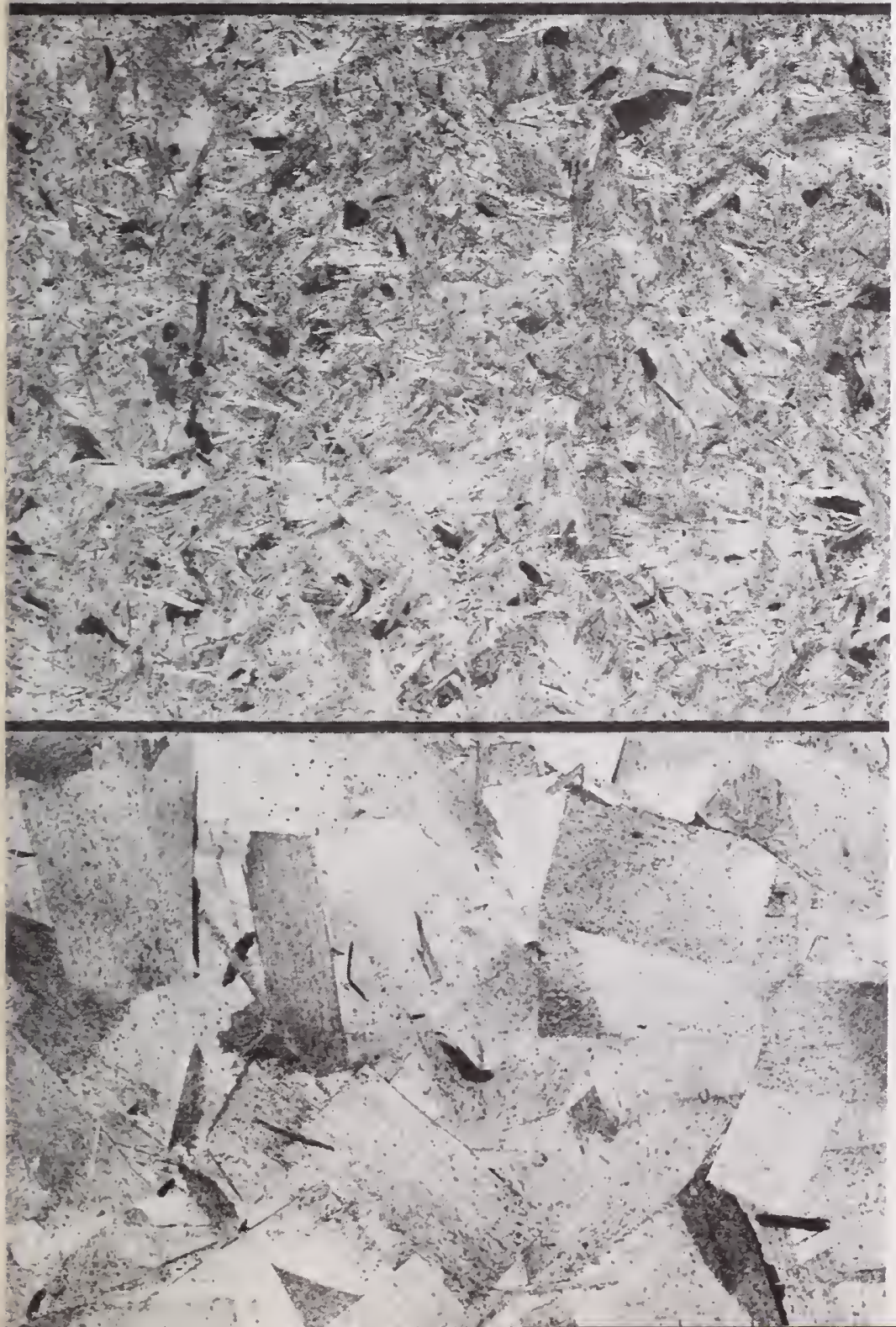

Rocky Mountain Forest and Range Experiment Station Forest Service U.S. Department of Agriculture Fort Collins, Colorado 80521 
Markstrom, Donald C., William F. Lehmann, and J. Dobbin McNatt.

1976. Technical feasibility of producing particleboard from Black Hills ponderosa pine. USDA For. Serv. Res. Pap. RM-173, 10 p. Rocky Mt. For. and Range Exp. Stn., Fort Collins, Colo. 80521.

Particleboards that met standard requirements for interior uses (floor underlayment, D-2 mobile home decking, and coreboard) and for exterior uses (bracing, siding, combination siding-sheathing, and combination subfloor underlayment) were made from ponderosa pine mill and logging residues in the laboratory. Six different types of board with varying particle geometry and distribution and with different resin contents and board densities were tested.

Keywords: Particleboard, wood waste, wood-using industries, Pinus ponderosa. 
USDA Forest Service

Research Paper RM-173

\section{Technical Feasibility of Producing Particleboard from Black Hills Ponderosa Pine}

Donald C. Markstrom, William F. Lehmann, and J. Dobbin McNatt 1

${ }^{1}$ Markstrom is Associate Wood Technologist, USDA Forest Service, Rocky Mountain Forest and Range Experiment Station, with central headquarters maintained at Fort Collins, in cooperation with Colorado State University; Lehmann and McNatt are Technologists, USDA Forest Service, Forest Products Laboratory, Madison, Wisconsin. 


\section{Contents}

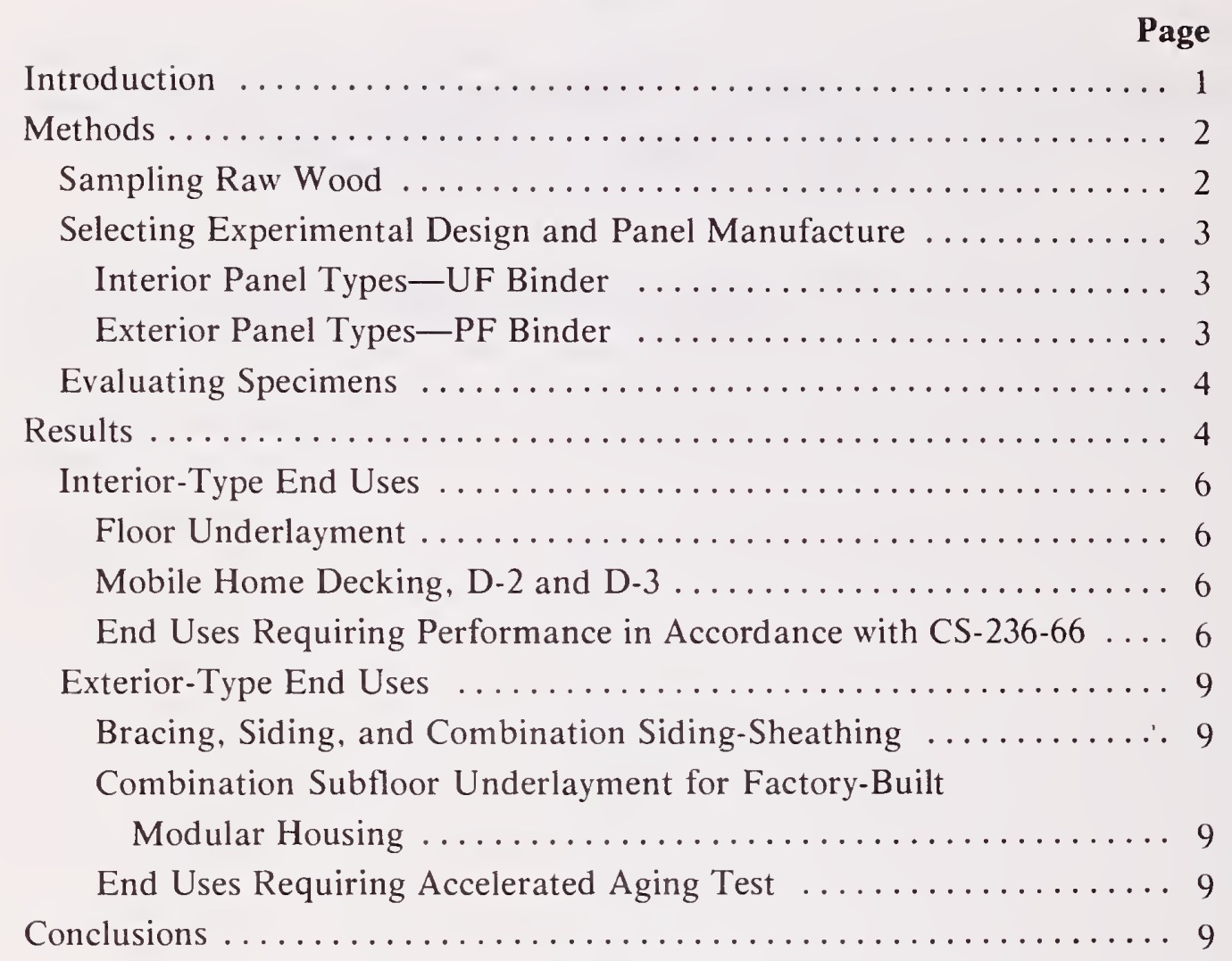




\title{
Technical Feasibility of Producing Particleboard from Black Hills Ponderosa Pine
}

\author{
Donald C. Markstrom, William F. Lehmann, and J. Dobbin McNatt
}

\section{INTRODUCTION}

In recent years, both private companies and public groups have expressed interest in particleboard production in the Black Hills region of South Dakota and Wyoming. Since this kind of industry appears to offer a needed means of expanding and diversifying timber utilization in the Black Hills, the U.S. Forest Service has initiated a series of studies to help evaluate the feasibility of such production. The study described here was designed to identify specific types of particleboard that can meet market and building code requirements, can be manufactured by existing or foreseeable processes, and could utilize locally available wood materials. Subsequent phases of the overall analysis will include: (1) market potentials, (2) amounts and kinds of raw material available, (3) required manpower, (4) plant investment and operating economics, and (5) economic and environmental impact on the community.

In previous technical evaluations, Barger and Fleischer ${ }^{2}$ and Wangaard et al. ${ }^{3}$ reported that boards manufactured from ponderosa pine with urea resin have suitable properties for floor underlayment and core stock. Also, since ponderosa pine particleboard is manufactured and widely marketed for furniture core stock and other uses, it must be assumed that these boards meet the technical requirements of the trade. However, complete data on the wide variety of particleboards that can potentially be made from ponderosa pine were not available in the literature. The overall objective of the technical phase of this study was therefore to determine the characteristics of

${ }^{2}$ Barger, Roland L., and Herbert O. Fleischer. 1964. New products from low-grade ponderosa pine timber. U.S. For. Serv. Res. Pap. RM-10, 54 p. Rocky Mt. For. and Range Exp. Stn., Fort Collins, Colo.

${ }^{3}$ Wangaard, F. F., F. C. Shirley, H. E. Troxell, R. S. Whaley, D. E. Eagen, and W. R. Wilcox. 1971. Potential markets for particleboard produced in the Rocky Mountains - Phase I. Unpublished report, Colorado State Univ., Dep. of Forest and Wood Sciences, Tech. Rep. Phase I. Rocky Mt. Forest and Range Exp. Stn. Res. Agreement 16-229-CT, CSU Project No. 1473, $34 p$. six different types of particleboard manufactured from various combinations of sawmill and logging residues to meet the technical requirements of selected end uses. Specific objectives were to determine the effect of geometry and distribution of particles and type and amount of resin on mechanical and physical properties.

\section{METHODS}

\section{Sampling Raw Wood}

A total sample of approximately 2,200 pounds of ponderosa pine (Pinus ponderosa) sawmill and forest residues was drawn at four sawmills and one logging site. All of the slabs, edgings, fine sawmill residues, and logging residue (tops) were sampled from freshly cut logs and trees. Planer shavings came from kilndried lumber.

Size distribution of the fine sawmill residues was determined with standard sieve screens. From geometrical shape and percentage of residues retained on each sieve (fig. 1), it is obvious that the sawing method used affected the character of the fine residues. Sawmill D, with a higher percentage of bigger particles, sawed with both chipping and circular headrigs; the other three mills used either circular or band headrigs with sashgang resaws.

The debarked slabs and edgings sampled were similar in appearance to those normally found at any Black Hills sawmill. The average specific gravity of these coarse residues was 0.39 , ovendry-weight and green-volume basis.

The logging residues were 14 top sections of trees harvested from a multiproduct sale. Some of the bolts were more irregular in shape than others, and contained large knots representative of those from big, yellow-bark ponderosa pine trees (fig. 2). Saw-log trees had been utilized to a 6 -inch top, and the small roundwood trees to about a 3.5-inch top. The tops had an average increment growth of 10.3 rings per inch and an average specific gravity of 0.40 , ovendryweight and green-volume basis. The diameter inside the bark at small ends of bolts ranged from 2.6 to 5.0 inches. 


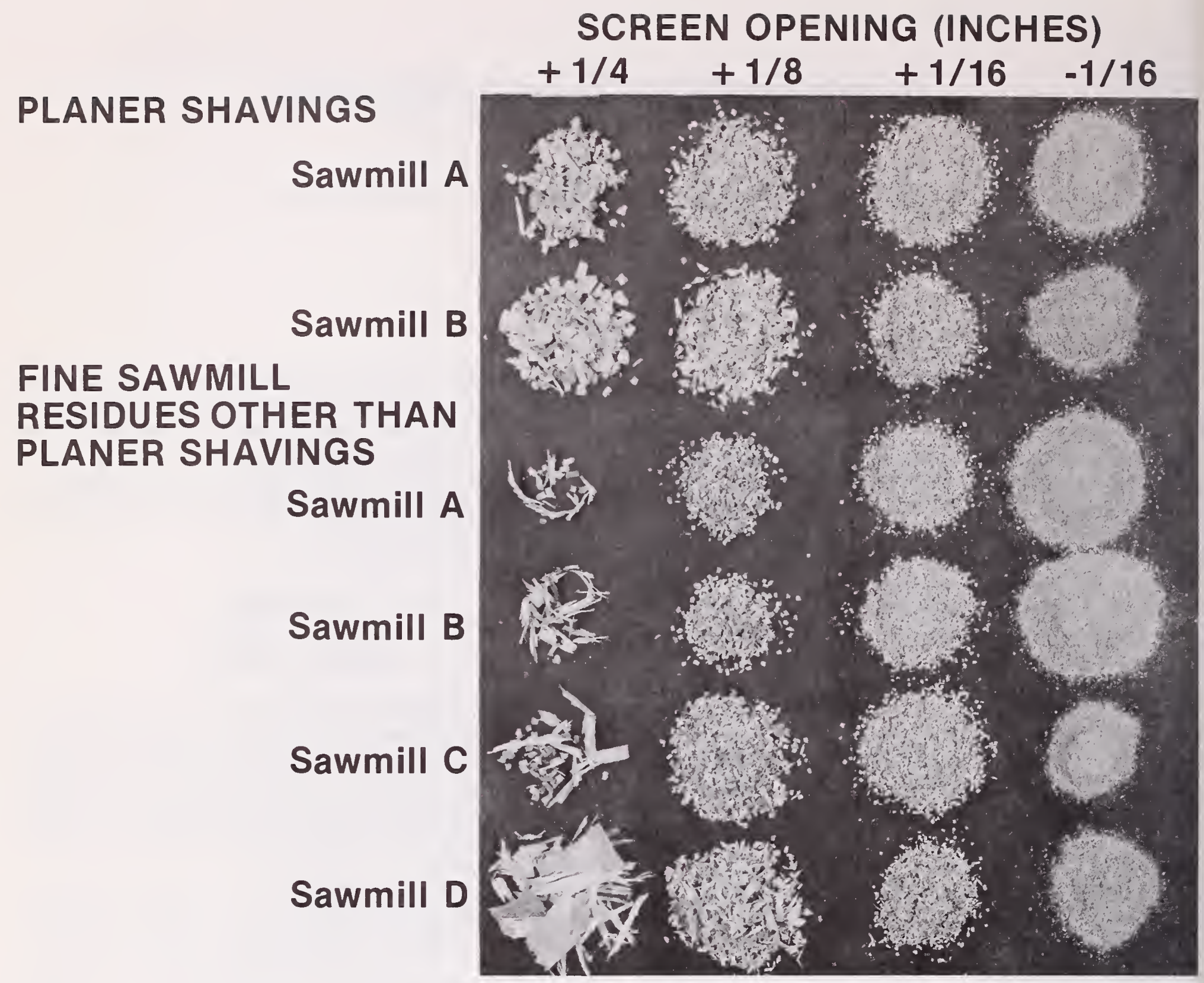

PERCENTAGE RETAINED ON EACH SCREEN AND THE PAN

PLANER SHAVINGS

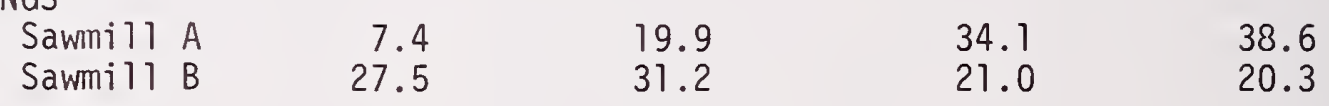

FINE SAWMILL RESIDUES OTHER THAN PLANER SHAVINGS

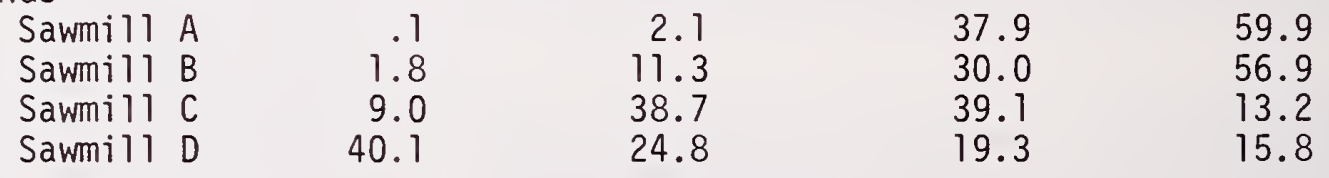

Figure 1. - Shape of planer shavings and other fine sawmill residues retained on each screen and the pan for each of four sawmills in the Black Hills, South Dakota. 


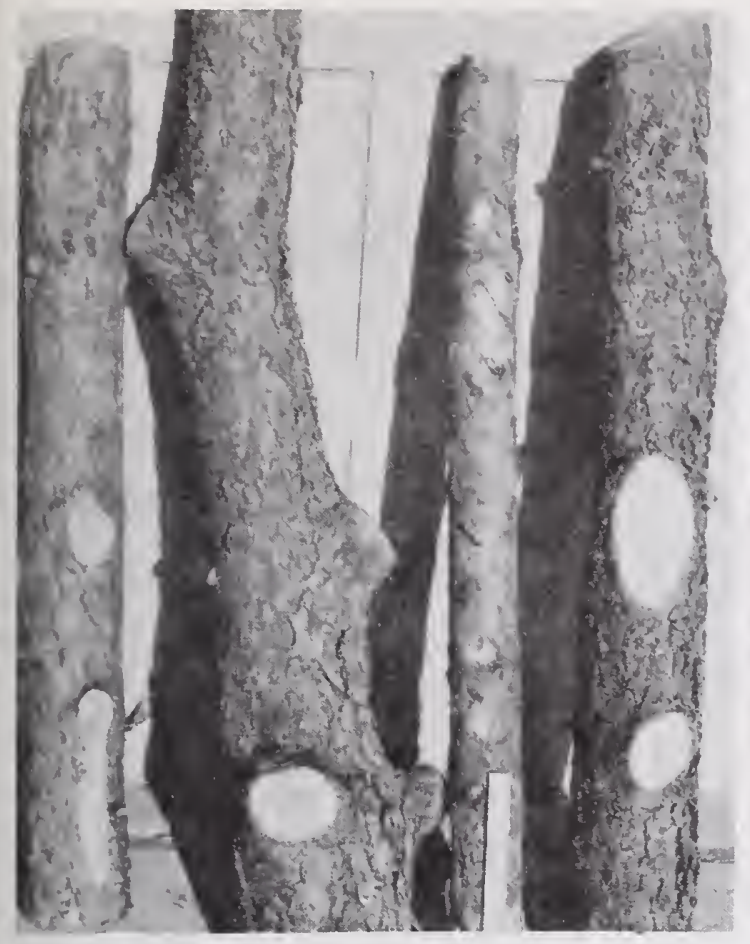

Figure 2.-Four-foot bolts cut from
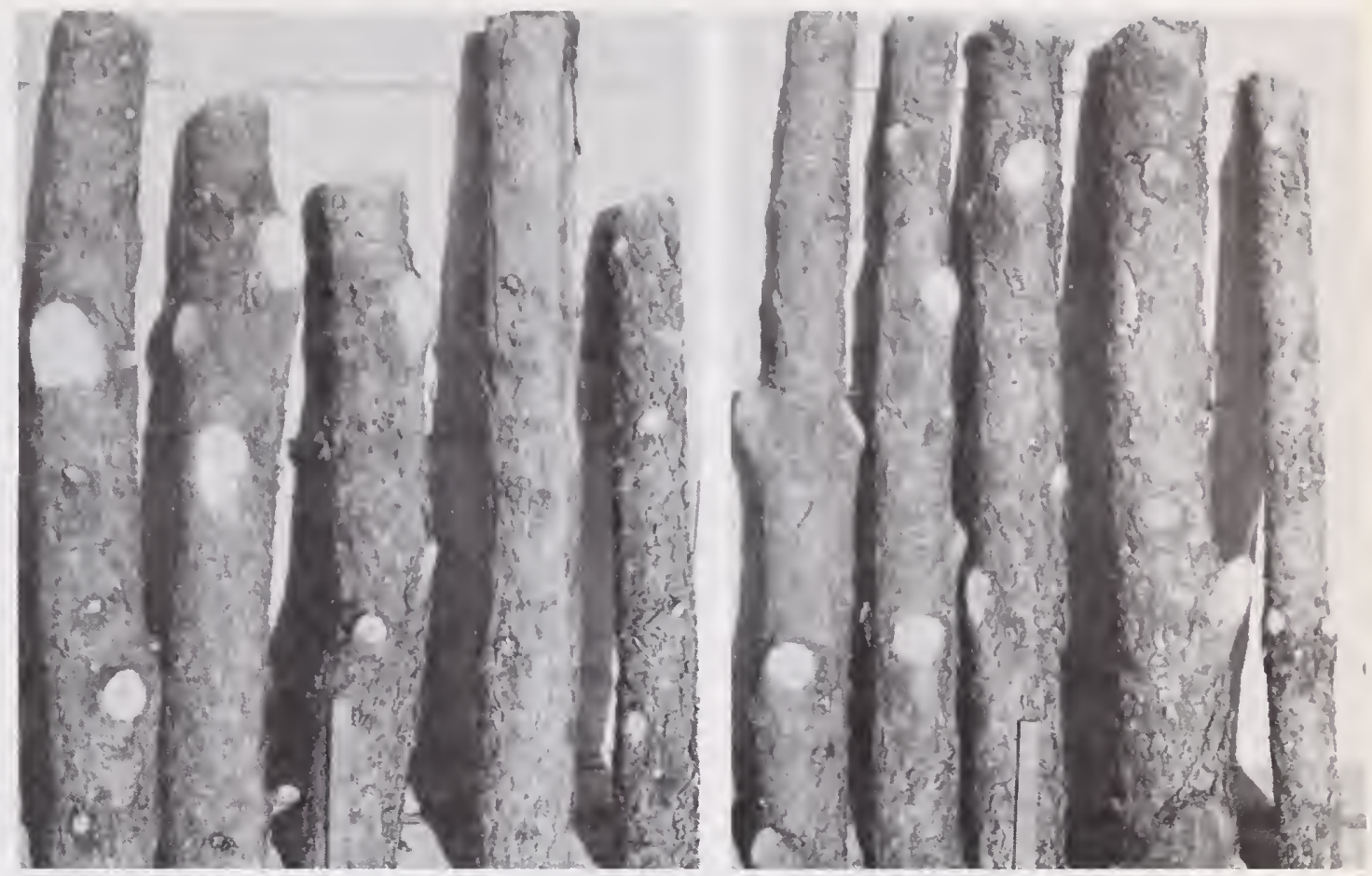

ponderosa pine logging residues (tops only) on a multiproduct sale in the Black Hills, South Dakota.

\section{Selecting Experimental Design and Panel Manufacture}

The six panel types selected for study are described below. Types 1 and 2 are interior boards with particle geometry and distribution and urea formaldehyde (UF) binder typical of most boards currently being marketed. Type 3, an exterior board, is similar to type 2 except the binder is phenol formaldehyde (PF). Types 4, 5, and 6 are exterior and structural types. Types 4 and 5 are experimental boards that should more efficiently utilize available raw materials than a homogeneous waferboard as represented by type 6 .

\section{Interior Panel Types-UF Binder}

Type 1.-Homogeneous fibrous board from solid wood residues. ${ }^{4}$

Type 2.-Three-layer commodity board, with faces of fine particles and core of coarse particles from refined shavings, sawdust, slabs, edgings, etc. ${ }^{5}$

\footnotetext{
${ }^{4}$ Includes slabs, edgings, and logging residues (without bark).

${ }^{5}$ Residues in panels $2-5$ used in proportions as in actual availability (50 percent solid wood, 31 percent sawdust, and 19 perceat shavings).
}

\section{Exterior Panel Types-PF Binder}

Type 3.-Three-layer commodity board, similar to type 2, except bonded with PF resin.

Type 4.-Three-layer flakeboard, with faces of larger flakes from solid wood residues processed through a ring flaker, and core of small flakes and refined shavings and sawdust.

Type 5.-Three-layer waferboard, with faces of wafers from solid wood residues processed through a disk flaker; cores similar to type 4 . Wafer implies a large, flat flake $0.020-0.025$ inch thick, 1.5 to 2 inches long, and of variable width.

Type 6.-Homogeneous waferboard, with wafers prepared from solid wood residues ${ }^{4}$ processed through a disk flaker.

The study was conducted as a series of small factorial experiments, each of which pertained to one of the six panel types. Experimental variables for each factorial design were two levels of board density ( 40 to 45 pounds per cubic foot); two levels of resin content ( 6 and 10 percent in panel types 1,2 , and 3 ; 3 and 5 percent in panel types 4, 5, and 6). Duplicate panels were prepared at each level for a total of eight panels per type. Thus, a total of 48 panels (six types $x$ two densities $x$ two resin contents $x$ two replications) were prepared in the study. 
The panels were manufactured generally according to standard laboratory procedures as follows:

\section{Panel size:}

Rough $-1 / 2$ by 24 by 28 inches

Trimmed $-1 / 2$ by $22-1 / 4$ by 26 inches.

Density:

40 or 45 pounds per cubic foot $\left(\mathrm{lb} / \mathrm{in}^{3}\right.$, based on ovendry weight and volume at 65 percent relative humidity (RH).

Resin content:

6 or 10 percent, types 1,2 , and $3 ; 3$ or 5 percent, types 4,5 , and 6 (based on ovendry weight of wood).

Wax content:

$1 / 2$ percent in UF panels, 1 percent in PF panels (based on ovendry weight of wood).

Catalyst:

1 percent in UF panels only (buffered 20 percent ammonium chloride solution).

Mat moisture content:

$10 \pm 1 / 2$ percent in UF panels (ovendry basis);

$8 \pm 1 / 2$ percent in PF panels (ovendry basis).

Press closing time:

1 minute to thickness.

Press cycle:

5 minutes at $325^{\circ} \mathrm{F}$ for UF panels; 7 minutes at $400^{\circ} \mathrm{F}$ for PF panels (high-density panels of type 6 were pressed 10 minutes at $300^{\circ} \mathrm{F}$ to avoid blisters).

Posttreatment:

UF panels were cooled immediately, PF panels were hot-stacked overnight in insulated box.

\section{Evaluating Specimens}

The following specimens were cut from each of the 48 panels (numbers in brackets indicate the number of evaluations for each panel):

Specimen 1: Static bending [2]

Modulus of elasticity (MOE).

Modulus of rupture (MOR).

Specimen 2: Internal bond [2]

Specimen 3: Humidity exposure-50-90 and 30-90 percent $R H$ [2]

Linear expansion.

Thickness swelling.

Moisture absorption.

Specimen 4: 24-hour water soak [2]

Linear expansion.

Thickness swelling.

Moisture absorption.

Specimen 5: Nailing properties [1]

Direct nail withdrawal.

Nailhead pullthrough.

Lateral nail resistance-3/8- and 1/2-inch edge distance.
Specimen 6: Accelerated aging-Panel types 3, 4, 5,

$6[2]$

Modulus of elasticity. ${ }^{6}$

Modulus of rupture. ${ }^{6}$

Internal bond strength.

Specimen 7: Direct screw withdrawal-Panel types 1 and 2 [2]

Face resistance.

Edge resistance.

Specimen 8: Hardness [4]

Specimens $1,2,5,6,7$, and 8 were conditioned to equilibrium moisture content at $80^{\circ} \mathrm{F}$ and 65 percent $\mathrm{RH}$ before testing; all were tested according to procedures specified in ASTM D 1037-72a.

\section{RESULTS}

The study results are presented and interpreted to compare the performance of the test boards (1) with each other, and (2) with current end-use standards. The latter comparison is particularly significant in selecting the most favorable product or products for the Black Hills area. Since some end uses do not require as high technical performance as others, it is critical to economic feasibility to keep the cost of manufacturing boards consistent with the end use and competitive with other products.

The boards were also tested for properties other than those required for present end uses, including some that may be required in revised standards for existing end uses or for new applications. The mean values for each property, together with the pooled error variance for each combination of board type, resin content, and density, are reported in table 1. The means are based on four observations except for nail withdrawal, nailhead pullthrough, and lateral nail resistance (two observations each), and hardness (eight observations).

Factorial analyses of the test data for the interiortype boards indicate that the three-layer commodity board surpassed the homogeneous fibrous board in modulus of elasticity (MOE), internal bond, hardness, and screw holding on both edge and face, but not in modulus of rupture (MOR) or nailing properties. The three-layer commodity board also had lower water absorption and thickness swell, but higher linear expansion, than the homogeneous board. The analysis also indicates that the boards with 10 percent resin had higher MOE, MOR, internal bond, hardness, screw holding on the edge and faces, and nailing properties than those with 6 percent resin. Resin

\footnotetext{
${ }^{6}$ Calculations of values based on specimen thickness before accelerated aging as specified in CS 236-66, SEC. 3.4.2.

71972 Annual Book of ASTM Standards, Part 16, D 1037-72a.
} 


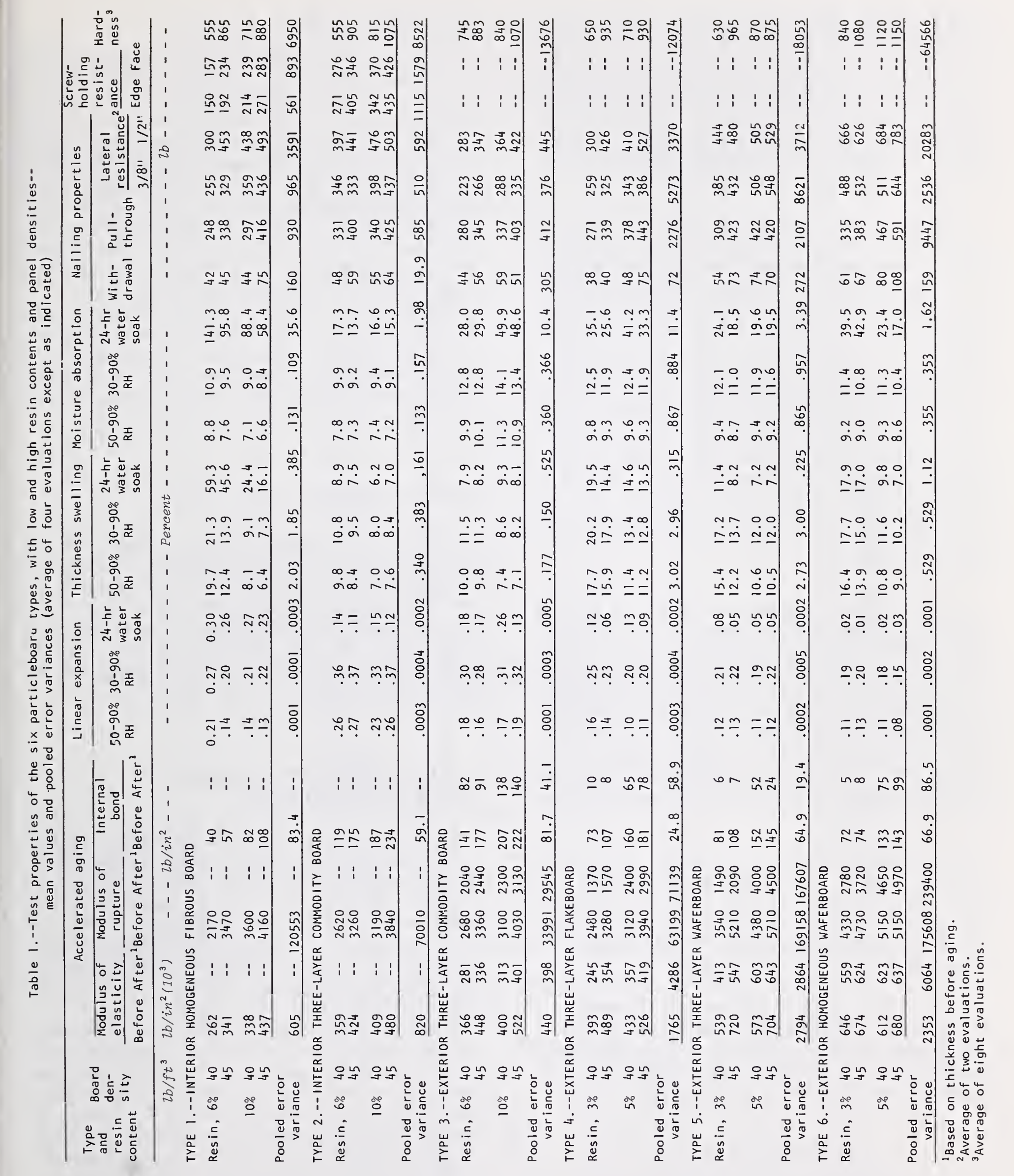


content also significantly interacted with board type to affect MOE, MOR, internal bond, linear expansion, thickness swell, and water absorption. Likewise, the boards of 45 density had higher MOE, MOR, internal bond, hardness, screw holding, and nailing properties than those of 40 . Board density also interacted with board type to affect internal bond, screw holding on edge, linear expansion, thickness swell, and water absorption.

Analysis of the test data for the exterior-type boards shows that both the three-layer waferboard and the homogeneous waferboard had a higher MOE and MOR, both before and after accelerated aging, than the three-layer flakeboard and the three-layer commodity board. The latter type had the highest internal bond, however, both before and after accelerated aging, probably due to its higher resin content. The waferboards also had the highest nail-holding strength. The homogeneous waferboard was hardest.

The most conspicuous results were the low internal bond strength of the exterior boards made with 3 percent resin after accelerated aging. The mean values for these boards ranged from only 5 to 10 pounds per square inch $\left(\mathrm{lb} / \mathrm{in}^{2}\right)$. Values for the same type of boards, both with 5 percent resin, ranged from 24 to $99 \mathrm{lb} / \mathrm{in}^{2}$.

Analysis shows that boards made with 5 percent resin had higher MOR, internal bond, nail withdrawal, and nailhead pullthrough, and had lower thickness swell and linear expansion, than those with 3 percent resin. MOE was not significantly affected by increasing the resin content. Resin content also interacted with board density to affect hardness. The boards with 45 density had higher MOE, MOR, internal bond, hardness, nail withdrawal, and nailhead pullthrough, and had lower thickness swell than those with 40 density.

After accelerated aging, the 5 percent resin boards had higher MOE, MOR, and internal bond than those with 3 percent resin. Likewise, the 45 boards had higher MOE and MOR than the 40 boards after accelerated aging. Board density also interacted with board type to affect the internal bond.

Tables 2 and 3 show whether test properties of the different particleboards passed the standard requirements for the particular uses. These are shown as one-sided 0.99 confidence limits, upper or lower, depending on the particular test property.

\section{Interior-Type End Uses}

Only the homogeneous fibrous board, type 1, and the three-layer commodity board, type 2 , both made with interior urea formaldehyde resin, were considered for these end uses.

\section{Floor Underlayment}

None of the homogeneous fibrous boards passed all of the floor underlayment requirements (table 2). The 6 percent urea, 40 combination was low in MOE, internal bond, and screw holding on both the face and edge. The thickness swell was especially high at 60 percent. The 8 percent urea, 45 combination failed in internal bond, thickness swell, and screw holding on the face. The 10 percent urea, 40 board failed in thickness swelling and screw holding on the face. The 10 percent urea, 45 board passed all of the property tests except thickness swell; additional wax probably would have been beneficial in this board type.

All of the three-layer commodity boards met the requirements except the 6 percent urea, 40 board, which failed the statistical test in screw holding on the face by only 2 pounds (table 2 ). The mean screwholding test value, however, exceeded the standard requirement by 51 pounds.

\section{Mobile Home Decking, D-2 and D-3}

None of the homogeneous fibrous boards had an adequate combination of properties for D-2 and D-3 decking. Mainly the MOE and internal bond were too low and thickness swell too high (table 2). None of the three-layer commodity board passed all of the D-3 requirements and only one-the 10 percent urea, 45 board-passed all of the D-2 requirements. Mainly the MOE was too low.

\section{End Uses Requiring Performance in Accordance with CS 236-66}

Type 1-B-1.-The property requirements specified in the Standard are the same as those for floor underlayment except for thickness swell, which is not specified for type 1-B-1 particleboard. Thus the results in table 2 and the discussion of results for floor underlayment apply equally well to 1-B-1 particleboard except for thickness swell. The markets for this board would include furniture, doors, kitchen cabinets, counter tops, and so forth.

Type 1-B-2.-The only homogeneous fibrous board passing all of the type 1-B-2 requirements was the 10 percent urea, 45 board. All other homogeneous fibrous boards were low in MOE and screw holding. Internal bond was also low for the 6 percent urea boards. MOR requirements were met by all boards except the 6 percent urea, 40 combination (table 2).

The only three-layer commodity board passing all the requirements was the 10 percent urea, 45 board. The others did not have adequate MOE, and the 6 percent urea, 40 board also lacked adequate MOR and screw holding on the face. 
Table 2.--Test properties ${ }^{1}$ of interior homogeneous fibrous boards and three-layer commodity boards compared with the standard requirements for floor underlayment, D-2 and D-3 mobile home decking, and Commercial Standard 236-66 (1-B-2)

\begin{tabular}{|c|c|c|c|c|c|c|c|c|c|}
\hline \multirow{2}{*}{$\begin{array}{l}\text { Type and } \\
\text { resin } \\
\text { content }\end{array}$} & \multirow{2}{*}{$\begin{array}{l}\text { Board } \\
\text { density }\end{array}$} & \multirow{2}{*}{$\begin{array}{l}\text { Modulus of } \\
\text { elasticity }\end{array}$} & \multirow{2}{*}{$\begin{array}{l}\text { Modulus of } \\
\text { rupture }\end{array}$} & \multirow{2}{*}{$\begin{array}{l}\text { Internal } \\
\text { bond }\end{array}$} & \multirow{2}{*}{$\begin{array}{c}\text { Linear } \\
\text { expansion } \\
50-90 \% \text { RH }\end{array}$} & \multirow{2}{*}{$\begin{array}{c}\text { Thickness } \\
\text { swell }\end{array}$} & \multicolumn{2}{|c|}{$\begin{array}{l}\text { Screwholding } \\
\text { resistance }\end{array}$} & \multirow{2}{*}{ Hardness } \\
\hline & & & & & & & Edge & Face & \\
\hline & $2 b / f t^{3}$ & -- & $-2 b / i n^{2}-$ & - & $--P$ & cent - - - & - & - - & $2 b$ \\
\hline $\begin{array}{l}\text { EQU IREMEN } \\
\text { RLAYMENT }{ }^{2}\end{array}$ & ${ }_{2}^{N T} F O R$ & $\geq 250,000$ & $\geq 1,600$ & $\geq 70$ & $\leq 0.35 \%$ & $\begin{array}{c}\leq 0.063 \\
10 \%\end{array}$ in. & $\geq 160$ & $\geq 225$ & -- \\
\hline
\end{tabular}

TYPE I.--INTERIOR HOMOGENEOUS FIBROUS BOARD

\begin{tabular}{|c|c|c|c|c|c|c|c|c|c|}
\hline Res in, & $6 \%$ & $\begin{array}{l}40 \\
45\end{array}$ & $\frac{229,000}{308,000}$ & $\begin{array}{l}1,705 \\
3,005\end{array}$ & $\frac{28}{45}$ & $\begin{array}{l}.22 \\
.15\end{array}$ & $\frac{60}{47}$ & $\frac{118}{160}$ & $\frac{117}{194}$ \\
\hline & $10 \%$ & $\begin{array}{l}40 \\
45\end{array}$ & $\begin{array}{l}305,000 \\
404,000\end{array}$ & $\begin{array}{l}3,135 \\
3,695\end{array}$ & $\begin{array}{l}70 \\
96\end{array}$ & $\begin{array}{l}.15 \\
.14\end{array}$ & $\frac{25}{17}$ & $\begin{array}{l}182 \\
239\end{array}$ & $\frac{199}{243}$ \\
\hline
\end{tabular}

TYPE 2.--INTERIOR THREE-LAYER COMMODITY BOARD

\begin{tabular}{|c|c|c|c|c|c|c|c|c|c|}
\hline \multirow[t]{2}{*}{ Resin, } & $6 \%$ & $\begin{array}{l}40 \\
45\end{array}$ & $\begin{array}{l}321,000 \\
386,000\end{array}$ & $\begin{array}{l}2,265 \\
2,905\end{array}$ & $\begin{array}{l}109 \\
165\end{array}$ & $\begin{array}{l}.28 \\
.29\end{array}$ & $\begin{array}{r}10 \\
8\end{array}$ & $\begin{array}{l}226 \\
360\end{array}$ & $\frac{223}{293}$ \\
\hline & $10 \%$ & $\begin{array}{l}40 \\
45\end{array}$ & $\begin{array}{l}371,000 \\
442,000\end{array}$ & $\begin{array}{l}2,835 \\
3,485\end{array}$ & $\begin{array}{l}177 \\
224\end{array}$ & $\begin{array}{l}.25 \\
.28\end{array}$ & $\begin{array}{l}7 \\
8\end{array}$ & $\begin{array}{l}297 \\
390\end{array}$ & $\begin{array}{l}317 \\
373\end{array}$ \\
\hline $\begin{array}{l}\text { REQUIRE } \\
\text { E HOME }\end{array}$ & $\begin{array}{l}\text { MENT } \\
\text { DECKI }\end{array}$ & $\begin{array}{l}\text { FOR } \\
N^{3}{ }^{3}\end{array}$ & $\geq 400,000$ & $\geq 2,400$ & $\geq 80$ & $\leq 0.30 \%$ & $\leq 8 \%$ & -- & -- \\
\hline
\end{tabular}

STANDARD REQUIREMENT FOR
D-2 MOBILE HOME DECKING

HOMOGENEOUS FIBROUS BOARD

TYPE I.--INTERIOR HOMOGENEOUS FIBROUS BOARD

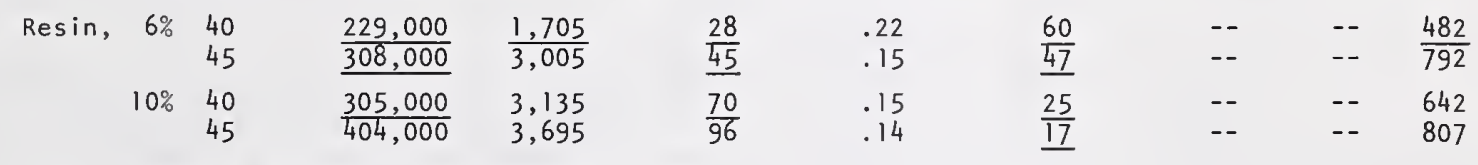

TYPE 2.--INTERIOR THREE-LAYER COMMODITY BOARD

\begin{tabular}{|c|c|c|c|c|c|c|c|c|c|c|}
\hline \multirow[t]{2}{*}{ Resin, } & $6 \%$ & $\begin{array}{l}40 \\
45\end{array}$ & $\frac{321,000}{386,000}$ & $\frac{2,265}{2,905}$ & $\begin{array}{l}109 \\
165\end{array}$ & $\begin{array}{l}.28 \\
.29\end{array}$ & $\frac{10}{8}$ & $\begin{array}{l}-- \\
--\end{array}$ & - & $\begin{array}{l}474 \\
824\end{array}$ \\
\hline & $10 \%$ & $\begin{array}{l}40 \\
45\end{array}$ & $\frac{371,000}{442,000}$ & $\begin{array}{l}2,835 \\
3,485\end{array}$ & $\begin{array}{l}177 \\
224\end{array}$ & $\begin{array}{l}.25 \\
.28\end{array}$ & $\begin{array}{l}7 \\
8\end{array}$ & -- & -- & $\begin{array}{l}734 \\
994\end{array}$ \\
\hline $\begin{array}{l}\text { REQUIRE } \\
\text { E HOME }\end{array}$ & $\begin{array}{l}\text { MENT } \\
\text { DECK }\end{array}$ & $\begin{array}{l}\text { FOR } \\
N^{3}{ }^{3}\end{array}$ & $\geq 450,000$ & $\geq 2,800$ & $\geq 80$ & $\leq 0.30 \%$ & $\leq 8 \%$ & -- & -- & $\geq 500$ \\
\hline
\end{tabular}

STANDARD REQUIREMENT FOR
D-3 MOB ILE HOME DECKING

TYPE 1.--INTERIOR HOMOGENEOUS FIBROUS BOARD

\begin{tabular}{|c|c|c|c|c|c|c|c|c|c|c|}
\hline Resin, & $6 \%$ & $\begin{array}{l}40 \\
45\end{array}$ & $\frac{229,000}{308,000}$ & $\frac{1,705}{3,005}$ & $\frac{28}{45}$ & $\begin{array}{l}.22 \\
.15\end{array}$ & $\frac{60}{47}$ & -- & -- & $\frac{482}{792}$ \\
\hline & $10 \%$ & $\begin{array}{l}40 \\
45\end{array}$ & $\begin{array}{r}305,000 \\
404,000 \\
\end{array}$ & $\begin{array}{l}3,135 \\
3,695\end{array}$ & $\frac{70}{96}$ & $\begin{array}{l}.15 \\
.14\end{array}$ & $\frac{25}{17}$ & -- & -- & $\begin{array}{l}642 \\
807\end{array}$ \\
\hline
\end{tabular}

TYPE 2.--INTERIOR THREE-LAYER COMMODITY BOARD

\begin{tabular}{|c|c|c|c|c|c|c|c|c|c|c|}
\hline Resin, & $6 \%$ & $\begin{array}{l}40 \\
45\end{array}$ & $\frac{321,000}{\underline{386,000}}$ & $\frac{2,265}{2,905}$ & $\begin{array}{l}109 \\
165\end{array}$ & $\begin{array}{l}.28 \\
.29\end{array}$ & $\frac{10}{8}$ & $\begin{array}{l}-- \\
--\end{array}$ & $\begin{array}{l}-- \\
--\end{array}$ & $\frac{474}{824}$ \\
\hline & $10 \%$ & $\begin{array}{l}40 \\
45\end{array}$ & $\frac{371,000}{442,000}$ & $\begin{array}{l}2,835 \\
3,485\end{array}$ & $\begin{array}{l}177 \\
224\end{array}$ & $\begin{array}{l}.25 \\
.28\end{array}$ & $\begin{array}{l}7 \\
8\end{array}$ & $\begin{array}{l}-- \\
--\end{array}$ & -- & $\begin{array}{l}734 \\
994\end{array}$ \\
\hline
\end{tabular}

STANDARD REQUIREMENT FOR

COMMERCIAL STANDARD 236-66

$(1-B-2)$

$\geq 400,000 \geq 2,400 \quad \geq 60 \quad \leq 0.30 \% \quad--\geq 200 \quad \geq 225$

TYPE 1.--INTERIOR HOMOGENEOUS FIBROUS BOARD

$\begin{array}{rllllllll}\text { Resin, } 6 \% & 40 & \frac{229,000}{308,000} & \frac{1,705}{3,005} & \frac{28}{45} & .22 & -- & \frac{118}{160} & \frac{117}{194} \\ & 45 & \frac{30}{405,000} & 3,135 & 70 & .15 & -- & \frac{182}{239} & \frac{199}{243}\end{array}$

TYPE 2.--INTERIOR THREE-LAYER COMMODITY BOARD

\begin{tabular}{|c|c|c|c|c|c|c|c|c|}
\hline Resin, $6 \%$ & $\begin{array}{l}40 \\
45\end{array}$ & $\frac{321,000}{386,000}$ & $\frac{2,265}{2,905}$ & $\begin{array}{l}109 \\
165\end{array}$ & $\begin{array}{l}.28 \\
.29\end{array}$ & -- & $\begin{array}{l}226 \\
360\end{array}$ & $\frac{223}{293}$ \\
\hline Resin, $10 \%$ & $\begin{array}{l}40 \\
45\end{array}$ & $\frac{371,000}{442,000}$ & $\begin{array}{l}2,835 \\
3,485\end{array}$ & $\begin{array}{l}177 \\
224\end{array}$ & $\begin{array}{l}.25 \\
.28\end{array}$ & -- & $\begin{array}{l}297 \\
390\end{array}$ & $\begin{array}{l}317 \\
373\end{array}$ \\
\hline
\end{tabular}

${ }^{1}$ One-sided 0.99 confidence limits, upper or lower depending on the test property, were compared with

the standard requirements. The property values not passing the standards are underlined.

${ }^{2}$ Commercial Standard CS 236-66; FHA Interim Revision No. 52 705-9.1, June 1971.

${ }^{3}$ National Particleboard Association Standard NPA 1-71. 
Table 3.--Test properties ${ }^{1}$ of exterior particle boards (types 3-6) compared with the standard requirements for bracing, siding, and combination siding-sheathing, and with those for combination subfloor underlayment

\begin{tabular}{|c|c|c|c|c|c|c|c|}
\hline & $\begin{array}{l}\text { Type and } \\
\text { resin } \\
\text { content }\end{array}$ & $\begin{array}{l}\text { Board } \\
\text { density }\end{array}$ & $\begin{array}{l}\text { Modulus of } \\
\text { elasticity }\end{array}$ & $\begin{array}{l}\text { Modulus of } \\
\text { rupture }\end{array}$ & $\begin{array}{l}\text { Internal } \\
\text { bond }\end{array}$ & $\begin{array}{c}\text { Linear } \\
\text { expansion } \\
50-90 \% \mathrm{RH}\end{array}$ & Hardness \\
\hline & & $2 b / f t^{3}$ & $-\cdots$ & $-2 b / i n^{2}-$ & -- & Percent & $2 b$ \\
\hline $\begin{array}{l}\text { STANDARD } \\
\text { BRAC ING, } \\
\text { COMB INATI }\end{array}$ & $\begin{array}{l}\text { REQU IREMEI } \\
\text { SIDING, AI } \\
\text { ION SIDING- }\end{array}$ & $\begin{array}{l}\text { NT FOR } \\
\text { ND } \\
\text {-SHEATHIN }\end{array}$ & $2 \geq 250,000$ & $\geq 1,800$ & $\geq 65$ & $\leq 0.35 \%$ & $\geq 500$ \\
\hline
\end{tabular}

TYPE 3.--EXTERIOR THREE-LAYER COMMODITY BOARD

\begin{tabular}{|c|c|c|c|c|c|c|c|}
\hline Res in & $6 \%$ & $\begin{array}{l}40 \\
45\end{array}$ & $\begin{array}{l}338,000 \\
420,000\end{array}$ & $\begin{array}{l}2,433 \\
3,113\end{array}$ & $\begin{array}{l}129 \\
165\end{array}$ & $\begin{array}{l}.19 \\
.17\end{array}$ & $\begin{array}{l}642 \\
780\end{array}$ \\
\hline & $10 \%$ & $\begin{array}{l}40 \\
45\end{array}$ & $\begin{array}{l}372,000 \\
494,000\end{array}$ & $\begin{array}{l}2,853 \\
3,783\end{array}$ & $\begin{array}{l}195 \\
210\end{array}$ & $\begin{array}{l}.18 \\
.20\end{array}$ & $\begin{array}{l}737 \\
967\end{array}$ \\
\hline
\end{tabular}

TYPE 4.--EXTERIOR THREE-LAYER FLAKEBOARD

\begin{tabular}{|c|c|c|c|c|c|c|c|}
\hline Resin & $3 \%$ & $\begin{array}{l}40 \\
45\end{array}$ & $\begin{array}{l}337,000 \\
433,000\end{array}$ & $\begin{array}{l}2,143 \\
2,943\end{array}$ & $\begin{array}{r}66 \\
100\end{array}$ & $\begin{array}{l}.18 \\
.16\end{array}$ & $\begin{array}{l}553 \\
838\end{array}$ \\
\hline & $5 \%$ & $\begin{array}{l}40 \\
45\end{array}$ & $\begin{array}{l}377,000 \\
470,000\end{array}$ & $\begin{array}{l}2,783 \\
3,603\end{array}$ & $\begin{array}{l}153 \\
174\end{array}$ & $\begin{array}{l}.12 \\
.13\end{array}$ & $\begin{array}{l}613 \\
833\end{array}$ \\
\hline
\end{tabular}

TYPE 5.--EXTERIOR THREE-LAYER WAFERBOARD

\begin{tabular}{|c|c|c|c|c|c|c|c|}
\hline Resin & $3 \%$ & $\begin{array}{l}40 \\
45\end{array}$ & $\begin{array}{l}468,000 \\
649,000\end{array}$ & $\begin{array}{l}2,989 \\
4,659\end{array}$ & $\begin{array}{l}70 \\
97\end{array}$ & $\begin{array}{l}.14 \\
.15\end{array}$ & $\begin{array}{l}512 \\
847\end{array}$ \\
\hline & $5 \%$ & $\begin{array}{l}40 \\
45\end{array}$ & $\begin{array}{l}502,000 \\
633,000\end{array}$ & $\begin{array}{l}3,829 \\
5,159\end{array}$ & $\begin{array}{l}141 \\
134\end{array}$ & $\begin{array}{r}.13 \\
.14\end{array}$ & $\begin{array}{l}752 \\
757\end{array}$ \\
\hline
\end{tabular}

TYPE 6.--EXTERIOR HOMOGENEOUS WAFERBOARD

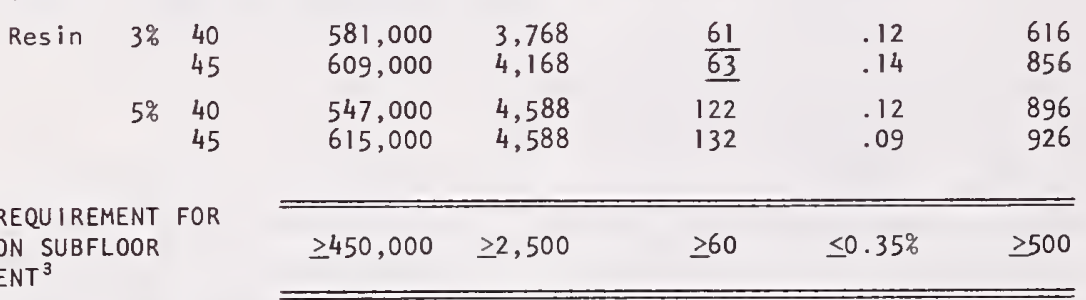

COMBINATION SUBFLOOR

THREE-LAYER COMMOOITY BOARD

TYPE 3.--EXTERIOR THREE-LAYER COMMOOITY BOARD

$\begin{array}{cccccccc}\text { Resin } & 6 \% & 40 & \frac{338,000}{420,000} & \frac{2,433}{3,133} & 129 & .19 & 642 \\ & 45 & \frac{372,000}{494,000} & 2,853 & 3,783 & 195 & .17 & 780 \\ & 10 \% & 40 & 45 & \frac{310}{19} & .18 & 737 \\ & 45 & & & & \end{array}$

TYPE 4.--EXTERIOR THREE-LAYER FLAKEBOARD

\begin{tabular}{|c|c|c|c|c|c|c|c|}
\hline Resin & $3 \%$ & $\begin{array}{l}40 \\
45\end{array}$ & $\begin{array}{l}337,000 \\
433,000\end{array}$ & $\frac{2,143}{2,943}$ & $\begin{array}{r}66 \\
100\end{array}$ & $\begin{array}{l}.18 \\
.16\end{array}$ & $\begin{array}{l}553 \\
838\end{array}$ \\
\hline & $5 \%$ & $\begin{array}{l}40 \\
45\end{array}$ & $\frac{377,000}{470,000}$ & $\begin{array}{l}2,783 \\
3,603\end{array}$ & $\begin{array}{l}153 \\
174\end{array}$ & $\begin{array}{r}.12 \\
.13\end{array}$ & $\begin{array}{l}613 \\
833\end{array}$ \\
\hline
\end{tabular}

TYPE 5.--EXTERIOR THREE-LAYER WAFERBOARD

\begin{tabular}{|c|c|c|c|c|c|c|c|}
\hline \multirow[t]{2}{*}{ Res in } & $3 \%$ & $\begin{array}{l}40 \\
45\end{array}$ & $\begin{array}{l}468,000 \\
649,000\end{array}$ & $\begin{array}{l}2,989 \\
4,659\end{array}$ & $\begin{array}{l}70 \\
97\end{array}$ & $\begin{array}{l}.14 \\
.15\end{array}$ & $\begin{array}{l}512 \\
847\end{array}$ \\
\hline & $5 \%$ & $\begin{array}{l}40 \\
45\end{array}$ & $\begin{array}{l}502,000 \\
633,000\end{array}$ & $\begin{array}{l}3,829 \\
5,159\end{array}$ & $\begin{array}{l}141 \\
134\end{array}$ & $\begin{array}{l}.13 \\
.14\end{array}$ & $\begin{array}{l}752 \\
757\end{array}$ \\
\hline
\end{tabular}

TYPE 6.--EXTERIOR HOMOGENEOUS WAFERBOARD

\begin{tabular}{|c|c|c|c|c|c|c|c|}
\hline \multirow[t]{2}{*}{ Resin } & $3 \%$ & $\begin{array}{l}40 \\
45\end{array}$ & $\begin{array}{l}581,000 \\
609,000\end{array}$ & $\begin{array}{l}3,768 \\
4,168\end{array}$ & $\begin{array}{l}61 \\
63\end{array}$ & $\begin{array}{l}.12 \\
.14\end{array}$ & $\begin{array}{l}616 \\
856\end{array}$ \\
\hline & $5 \%$ & $\begin{array}{l}40 \\
45\end{array}$ & $\begin{array}{l}547,000 \\
615,000\end{array}$ & $\begin{array}{l}4,588 \\
4,588\end{array}$ & $\begin{array}{l}122 \\
132\end{array}$ & $\begin{array}{l}.12 \\
.09\end{array}$ & $\begin{array}{l}896 \\
926\end{array}$ \\
\hline
\end{tabular}

${ }^{1}$ One-sided 0.99 confidence 1 imits, upper or lower depending on the test property, were compared with the standard requirements. The property values not passing the standards are underlined.

${ }^{2}$ FHA Use of Materials, No. UM32, June 1961; Uniform Building Code, 1970 edition; and FHA Tech. Circ. No. 12.

${ }^{3}$ FHA Use of Materials, No. UM57, and National Particleboard Association Standard NPA 2-70. 


\section{Exterior-Type End Uses}

All the boards manufactured with exterior phenol formaldehyde resin were considered for these end uses.

\section{Bracing, Siding, and \\ Combination Siding-Sheathing}

All of the exterior three-layer commodity boards exceeded the property requirements listed in table 3 for the above uses. The internal bonds for these boards were especially high. Likewise, all of the three-layer flakeboards and three-layer waferboards exceeded property requirements. The homogeneous waferboards likewise performed satisfactorily, except for the 3 percent resin, 40 and 45 boards. The internal bond of these boards was low.

\section{Combination Subfloor Underlayment for Factory-Built Modular Housing}

The only three-layer commodity board with a high enough MOE plus adequate values in other properties was the 10 percent resin, 45 board (table 3 ). The MOR for the 6 percent resin, 40 board was also low.

Similarly, the only three-layer flakeboard having high enough MOE and adequate values in other properties for these end uses was the 5 percent resin, 45 board. The MOR was also low for the 3 percent resin, 40 board. All of the three-layer waferboards and the homogeneous waferboards exceeded standard requirements.

\section{End Uses Requiring Accelerated Aging Test}

Some exterior uses require particleboard to pass the accelerated aging test as specified in Commercial Standard CS 236-66 in addition to the other requirements. The Standard states that the minimum MOR after aging should be not less than 50 percent of the original minimum average MOR. All boards passed the accelerated aging requirement except three - the 45 three-layer tlakeboard and the 40 and 45 threelayer waferboards with 3 percent resin (table 4). The internal bond of these three boards was also low after accelerated aging.

\section{CONCLUSIONS}

We made experimental particleboards that met standard requirements for interior uses (floor underlayments, D-2 mobile home decking, and coreboard) and for exterior uses (bracing, siding, combination siding-sheathing, and combination subfloor underlayment) from mill and logging residues of Black Hills ponderosa pine. The acceptability of each board
Table 4.--Modulus of rupture of exterior particleboard, before and after accelerated aging

\begin{tabular}{|c|c|c|c|}
\hline \multirow{2}{*}{$\begin{array}{l}\text { Type and } \\
\text { resin } \\
\text { content }\end{array}$} & \multirow{2}{*}{$\begin{array}{c}\text { Board } \\
\text { density }\end{array}$} & \multicolumn{2}{|c|}{ Modulus of rupture } \\
\hline & & Before & After \\
\hline & $z b / f t^{3}$ & - - & - - \\
\hline
\end{tabular}

$\begin{array}{rrrrr}\text { Resin } 6 \% & 40 & 2,680 & 2,040 \\ & 45 & 3,360 & 2,440 \\ 10 \% & 40 & 3,100 & 2,300 \\ & 45 & 4,030 & 3,130\end{array}$

TYPE 4.--EXTERIOR THREE-LAYER FLAKEBOARD

$\begin{array}{rrrrr}\text { Resin } 3 \% & 40 & 2,480 & 1,370 \\ & 45 & 3,280 & 1,570 \\ & 5 \% & 40 & 3,120 & 2,400 \\ & 45 & 3,940 & 2,990\end{array}$

TYPE 5.--EXTERIOR THREE-LAYER WAFERBOARD

$\begin{array}{lllll}\text { Resin } & 3 \% & 40 & 3,540 & \frac{1,490}{2,090} \\ & & 45 & 5,210 & \underline{2,000} \\ \text { Resin } & 5 \% & 40 & 4,380 & 4,500\end{array}$

TYPE 6.--EXTERIOR HOMOGENEOUS WAFERBOARD

$\begin{array}{lllll}\text { Resin } & 3 \% & 40 & 4,330 & 2,780 \\ & 45 & 4,730 & 3,720 \\ & 5 \% & 40 & 5,150 & 4,650 \\ & 45 & 5,150 & 4,970\end{array}$

I When the accelerated aging test is required, the standard states that the minimum mean modulus of rupture of the samples ahll not be less than $50 \%$ of minimum mean modulus of rupture of samples not exposed to the aging test, Commercial Standard CS 236-66. The property values not passing the standards are underlined.

type, resin content, and board density combination for these uses is summarized in tables 5 and 6 . Also noted in table 5 are the boards rejected only because of thickness swell. Acceptability is based upon requirements and performances previously described.

The three-layer interior commodity board with 6 percent resin and density of 40 should be investigated further for both floor underlayment and uses requiring type 1-B-1 performance. The board passed all property requirements for the two uses except screw holding on the face, which was nearly acceptable (see table 2). This board closely resembles the typical commercial "commodity" type board being mass produced for these two uses in both raw material and other manufacturing characteristics. 
Table 5.--Acceptability of interior particleboards for floor underlayment, D-2 and D-3 mobile home decking, and other uses that require the performance of boards $1-B-1$ and $1-B-2$ in Commercial Standard CS 236-66

\begin{tabular}{cccccc}
\hline $\begin{array}{c}\text { Type and } \\
\text { resin } \\
\text { content }\end{array}$ & $\begin{array}{c}\text { Board } \\
\text { density }\end{array}$ & $\begin{array}{c}\text { Floor } \\
\text { underlayment }\end{array}$ & $\frac{\begin{array}{c}\text { Mobile home } \\
\text { decking }\end{array}}{D-2}$ & CSC 236-66 performance \\
\hline
\end{tabular}

\begin{tabular}{|c|c|c|c|c|c|c|}
\hline Res in & $6 \%$ & $\begin{array}{l}40 \\
45\end{array}$ & $\begin{array}{l}\text { No } \\
\text { No }\end{array}$ & $\begin{array}{l}\text { No } \\
\text { No }\end{array}$ & $\begin{array}{l}\text { No } \\
\text { No }\end{array}$ & $\begin{array}{l}\text { No } \\
\text { No }\end{array}$ \\
\hline & $10 \%$ & $\begin{array}{l}40 \\
45\end{array}$ & $\begin{array}{l}\text { No } \\
\text { No }\end{array}$ & $\begin{array}{l}\text { No } \\
\text { No }^{1}\end{array}$ & $\begin{array}{l}\text { No } \\
\text { No }\end{array}$ & $\begin{array}{l}\text { No } \\
\text { Yes }\end{array}$ \\
\hline
\end{tabular}

TYPE 2.--INTERIOR THREE-LAYER COMMODITY BOARD

$\begin{array}{ccllllll}\text { Resin } 6 \% & 40 & \text { No } & \text { No } & \text { No } & \text { No }^{2} & \text { No } \\ & 45 & \text { Yes } & \text { No } & \text { No } & \text { Yes } & \text { No } \\ & 10 \% & 40 & \text { Yes } & \text { No } & \text { No } & \text { Yes } & \text { No } \\ & 45 & \text { Yes } & \text { Yes } & \text { No } & \text { Yes } & \text { Yes }\end{array}$

\footnotetext{
${ }^{1}$ Rejected because of thickness swell.

${ }^{2}$ Failed statistical test by only 2 pounds in screwholding on face.
}

Table 6.--Acceptability of exterior particleboards for bracing, siding, combination siding-sheathing, and for combination subfloor under layment

\begin{tabular}{lll}
\hline $\begin{array}{l}\text { Type and } \\
\text { resin } \\
\text { content }\end{array}$ & $\begin{array}{l}\text { Bracing, siding, } \\
\text { density }\end{array}$ & $\begin{array}{l}\text { and combination } \\
\text { siding-sheathing underlayment }\end{array}$ \\
\hline
\end{tabular}

TYPE 3.--EXTERIOR THREE-LAYER COMMODITY BOARD

$\begin{array}{llll}\text { Resin } 6 \% & 40 & \text { Yes } & \text { No } \\ & 45 & \text { Yes } & \text { No } \\ 10 \% & 40 & \text { Yes } & \text { No } \\ & 45 & \text { Yes } & \text { Yes }\end{array}$

TYPE 4.--EXTERIOR THREE-LAYER FLAKEBOARD

$\begin{array}{llll}\text { Resin } 3 \% & 40 & \text { Yes } & \text { No } \\ & 45 & \text { Yes } & \text { No } \\ & 4 \% & \text { Yes } & \text { No } \\ & 40 & \text { Yes } & \text { Yes }\end{array}$

TYPE 5.--EXTERIOR THREE-LAYER WAFERBOARD

$\begin{array}{llll}\text { Resin } 3 \% & 40 & \text { Yes } & \text { Yes } \\ & 45 & \text { Yes } & \text { Yes } \\ & 4 \% & \text { Yes } & \text { Yes } \\ & 45 & \text { Yes } & \text { Yes }\end{array}$

TYPE 6.--EXTERIOR HOMOGENEOUS WAFERBOARD

\begin{tabular}{|c|c|c|c|}
\hline Resin & $3 \%$ & $\begin{array}{l}40 \\
45\end{array}$ & $\begin{array}{l}\text { No } \\
\text { No }\end{array}$ \\
\hline & $5 \%$ & $\begin{array}{l}40 \\
45\end{array}$ & $\begin{array}{l}\text { Yes } \\
\text { Yes }\end{array}$ \\
\hline
\end{tabular}

It appears that a resin content of 3 percent is not high enough to develop adequate internal bonds for boards exposed to exterior conditions simulated by the accelerated aging test. Boards with 5 or more percent resin performed well, however, when exposed to accelerated aging (see table 1).

It is important to note that the two conventional exterior board types-three-layer commodity and three-layer flakeboard-both performed as adequately as the three-layer waferboard and the homogeneous waferboard for the exterior uses of bracing, siding, and combination siding-sheathing.

Also of importance was the adequate performance of the 45 three-layer flakeboard with 5 percent resin for combination subfloor underlayment uses. These conventional boards can be manufactured with lower cost raw material from large residue surpluses in most lumber and plywood manufacturing areas. Typically, stumpage and harvesting costs are not charged against these residues. Only the costs of handling the residues and hauling them from the sawmill or plywood plant to the particleboard plant are charged. By contrast, when roundwood is used, the particleboard operation must pay the total cost of stumpage, harvesting, hauling, and handling. 


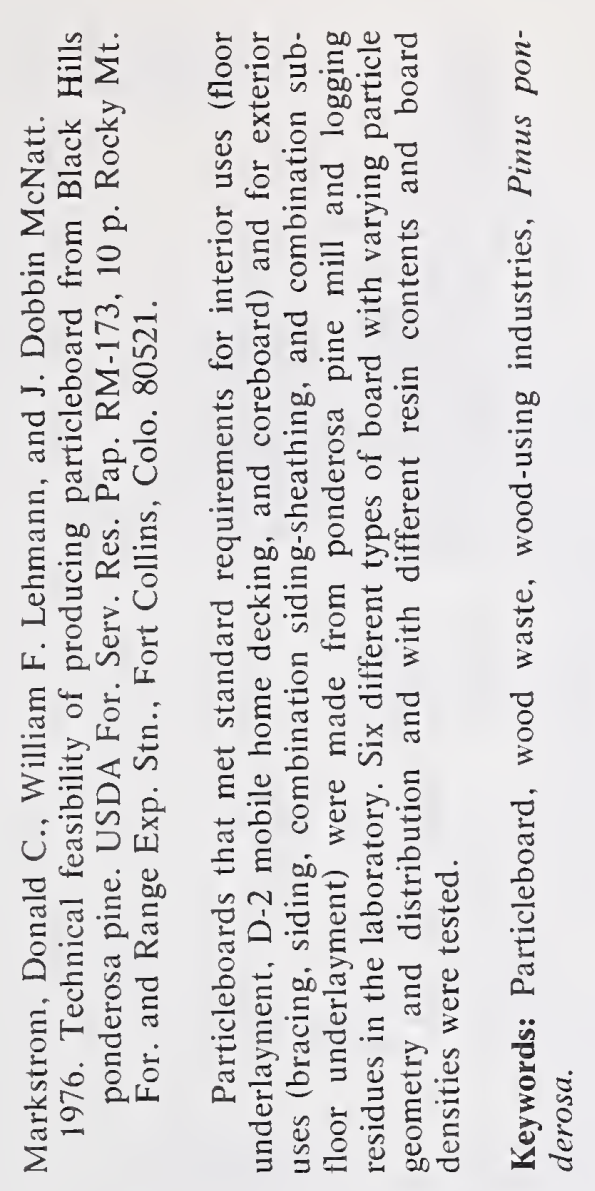

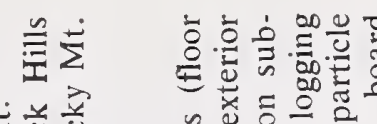

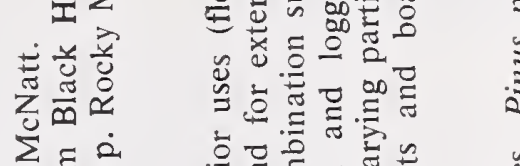

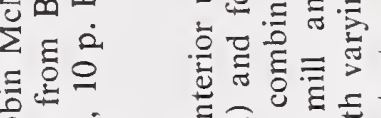

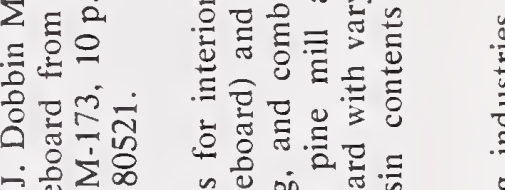

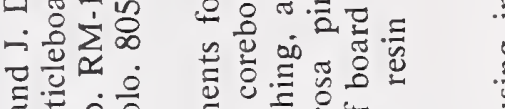

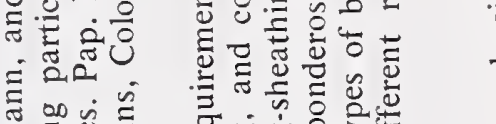

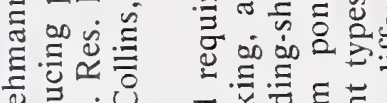

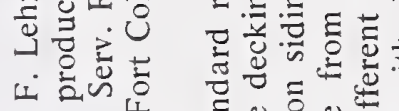

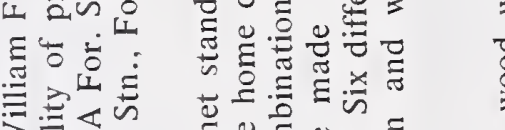

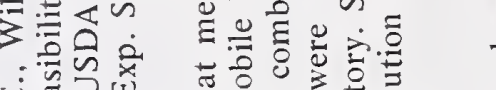

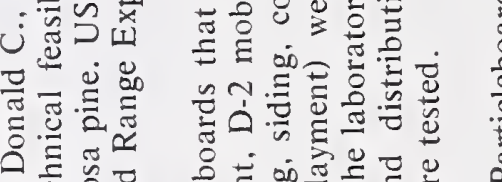

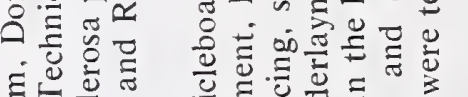

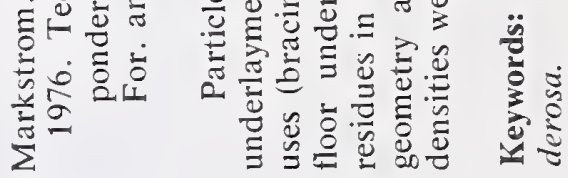

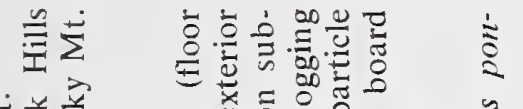

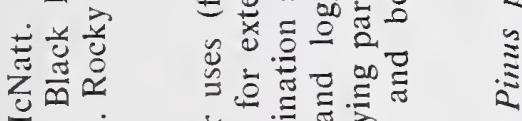

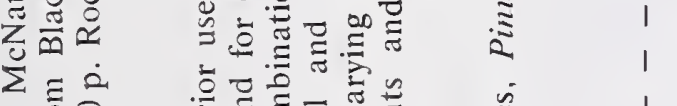

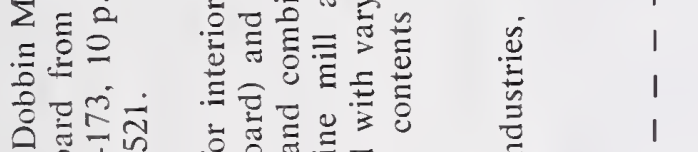

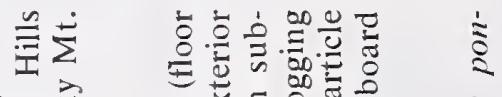

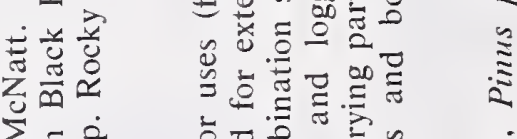

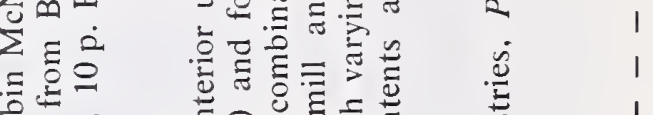

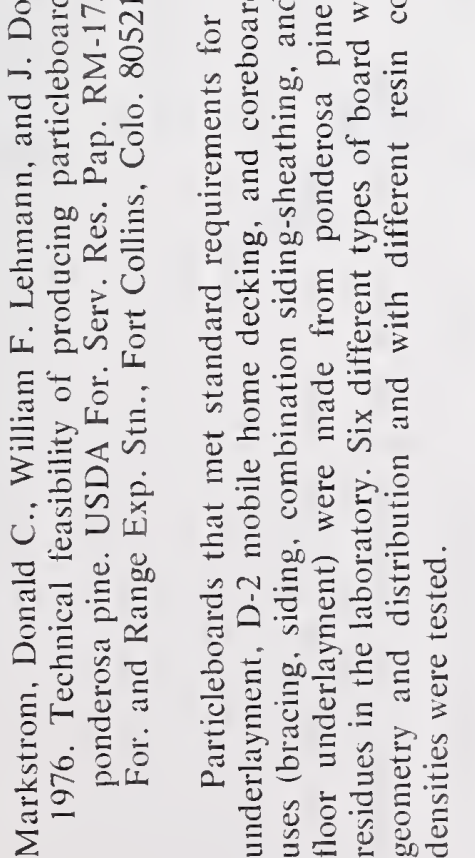

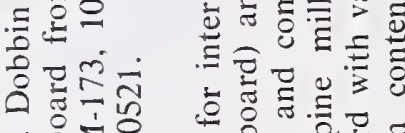

$\therefore: \sum_{0}$ 定

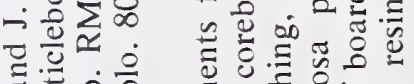

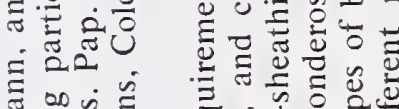

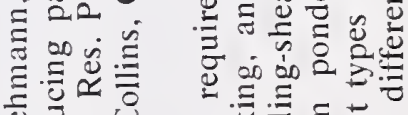

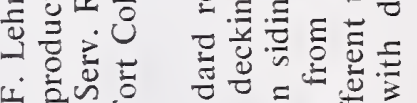

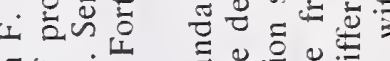

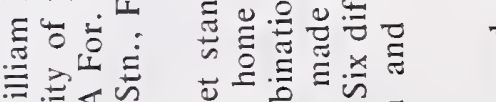

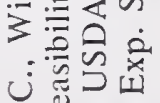

चِّ.

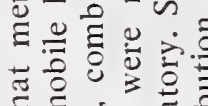

ธง

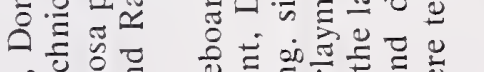

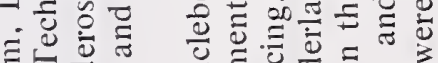

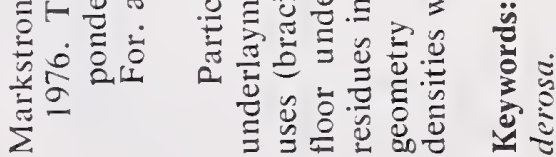




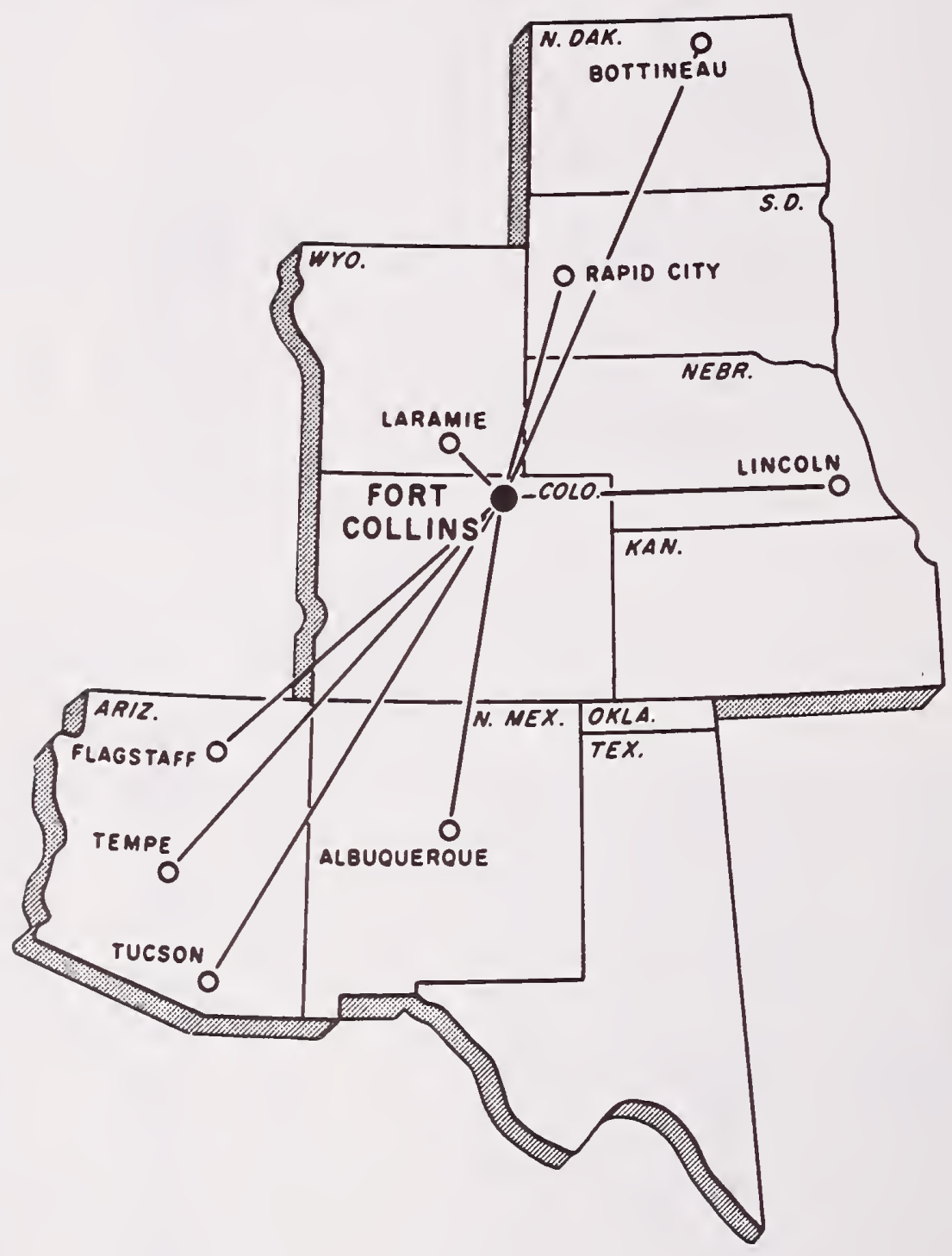

